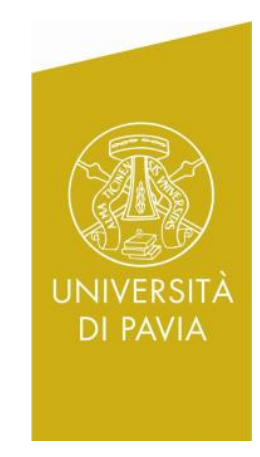

Department of Economics and Management DEM Working Paper Series

\title{
FOOD COMPETITION IN WORLD MARKETS: SOME EVIDENCE FROM A PANEL DATA ANALYSIS OF TOP EXPORTING COUNTRIES
}

\author{
Donatella Baiardi \\ (Università Bicocca Milano) \\ Carluccio Bianchi \\ (Università di Pavia) \\ Eleonora Lorenzini \\ (Università di Pavia)
}

\author{
\# 60 (12-13) \\ Via San Felice, 5 \\ I-27100 Pavia \\ http://epmq.unipv.eu/site/home.html
}

December 2013 


\title{
FOOD COMPETITION IN WORLD MARKETS: SOME EVIDENCE FROM A PANEL DATA ANALYSIS OF TOP EXPORTING COUNTRIES
}

\author{
Donatella Baiardi ${ }^{\S}, *, \circ$ \\ donatella.baiardi@unimib.it \\ Carluccio Bianchi ${ }^{\S}$ \\ cbianchi@eco.unipv.it \\ Eleonora Lorenzini ${ }^{\S}$ \\ eleonora.lorenzini@unipv.it \\ ${ }^{\S}$ Dipartimento di Scienze Economiche e Aziendali \\ Università degli Studi di Pavia \\ Via San Felice, 5 - I27100, Pavia \\ $\circ$ Corresponding author \\ *Dipartimento di Economia, Metodi Quantitativi e Strategie d'Impresa \\ Università Milano Bicocca \\ Via degli Arcimboldi 8, Edificio U7- I20126, Milano
}

\begin{abstract}
This paper investigates the relationships between export price and income elasticities, average unit values (AUVs) and market shares for the top world food exporters in the time period 1992-2011 using a panel data framework. Emerging countries and Spain show a high price elasticity unlike other advanced countries. Moreover, an inverse relationship between price elasticities and AUVs is found to exist. The overall analysis enables the conclusion that advanced countries can maintain a specialization in low-tech sectors only if high prices, as indicators of high quality, are accompanied by a rigid foreign demand and a satisfactory income elasticity of exports.
\end{abstract}

JEL: F14, L66, Q17, C23

Keywords: Food Exports, Price elasticity, Income elasticity, Panel Granger causality 


\section{Introduction}

Since the 1960s, a new wave of globalization has quickened the pace of world integration. International trade has played a key role in this process, as shown by an unprecedented increase in export growth rate, stimulated also by the liberalization process promoted by the WTO multilateral trade negotiations during the 1990s. Despite its nature of a necessary good, and the persistence of many protectionist policies, food is an important element of world merchandise trade with an incidence on total exports slightly below 10 per cent (see Table 1). ${ }^{1}$ Although this percentage is declining, food continues to play a primary role in total exports of both advanced and emerging countries.

Table 1 about here

The most remarkable case is Argentina, where food accounts for 50 per cent of exports on average over the period 1992-2011, ${ }^{2}$ followed by Brazil, Thailand and the Netherlands (28.04, 16.10 and 15.52 per cent respectively). Moreover, in countries like Brazil, Canada, Indonesia, and Malaysia, the share of food on total exports has increased in the last twenty years. These figures show that a traditional low-tech sector like food can still represent an important growth-driver, supporting GDP, employment and the balance of payments. Furthermore, traditional low-tech industries can be key contributors in terms of a country's quality reputation and excellence, triggering positive externalities for the whole economy.

In identifying the factors determining export performance, the literature highlights foreign income as the most important variable for trade in general (KRUGMAN, 1989; IRWIN, 2002 and ESTEVADEORDAL ET AL., 2003) and for agricultural products in particular (see Coyle et Al., 1998; Haq \& MeIlKe, 2009 and Serrano \& Pinilla, 2010). Moreover, KRUGMAN (1989) observes that in the long-run Purchasing Power Parity (PPP) holds as a general tendency, so that different export growth rates across

\footnotetext{
${ }^{1}$ As a confirmation of the huge increase in international trade in the second-globalization era, both total and food exports grew very rapidly and significantly faster than production (SERRANO \& PINILLA, 2010), as proved by their historical income elasticities, showing values greater than 1 during the last twenty years (1.7 and 1.1 respectively).

${ }^{2}$ This is the time span used in the analysis.
} 
countries are principally determined by non-price competitiveness, as empirically reflected in income elasticities (see also CAPORALE \& CHIU, 1999). However, it should be noticed that the PPP theory holds only for tradable goods at the aggregate level and in the very long-run, when real exchange rates show no substantial change and thus have no central role in export performance. In the short and medium-run, and even in time spans as long as a decade, evidence in favour of the validity of the PPP theory is not definite, so that countries may experience changes in their relative export prices which modify their competitiveness (GOLDBERG \& KNETTER, 1997 and KRUGMAN, 1987). Hence, especially at a disaggregated level, relative prices matter, and price elasticities are as important as income elasticities in export performance.

When price competiveness is considered, standard international trade theory underlines the advantage of having higher price elasticities, because of their favorable effects on export volumes and the balance of payments. ${ }^{3}$ However, this orthodox argument holds only either for the whole economy or for undifferentiated products depending on price competition. Many studies, moreover, show that prices are indicators of quality (AIGINGER, 1997 and SCHOTT, 2004), so that high relative prices, when they signal a high quality standard of goods, are not necessarily disadvantageous in trade competition. Product quality can actually be a discriminating factor for the success or decline of low-tech products and even advanced countries can successfully compete in traditional industries if they rely on high-quality rather than low-price exports. In particular, countries characterized by high prices and quality reputation are likely to exhibit a more rigid foreign demand for their products. However, as time goes by, demand can become more elastic if international markets recognize a decrease in product quality so that there will be a shift toward products from countries with the same quality but lower prices. On the contrary, despite higher prices, foreign demand can remain rigid if world consumers recognize the superiority of a country's products and are willing to pay more for high-quality goods. Ultimately, our working hypothesis is that advanced countries characterized by high relative prices and a rigid export demand can successfully compete in low-tech products on international markets. In this context, the food industry is an interesting case study since in several countries it is a

\footnotetext{
${ }^{3}$ In fact, the Marshall-Lerner condition suggests that the higher the price elasticities of exports and imports, and thus their sum, the greater the effects of a relative price change on trade volumes and foreign currency net inflows.
} 
large traditional sector which provides a relevant contribution to employment and value added. It also generates positive economic and social externalities in terms of reputation, tourism attraction and environmental protection.

The empirical analysis developed in this paper is original for the following reasons. First, in line with the most recent applied econometric literature on panel data, it tests the relevance of relative prices and world income as determinants of food exports for the top 15 trading countries (Argentina, Brazil, Belgium, Canada, China, France, Germany, Indonesia, Italy, Malaysia, Netherlands, Spain, Thailand, UK and USA) in the time period 1992-2011. Second, it shows that average unit values (AUVs) can be interpreted as indicators of quality when they are analyzed together with price elasticities and market shares. In particular, this paper investigates the existence of an inverse relationship between AUVs and export price elasticities, in order to verify the hypothesis that countries with higher AUVs will generally show a more rigid foreign demand and vice versa. ${ }^{4}$ On this point, then, we depart from orthodox literature where quality is usually captured by the export income elasticity, which is thought to reflect the so-called non-price competitiveness of a country, also influenced by other factors like composition of exports, destination markets, embodied technology, marketing strategies and promotion, distribution services, financial assistance to exporters, and so on. Finally, the paper proposes a classification of the sample countries on the basis of the empirical results reached, deriving some conclusions about their competitiveness on world markets. Our claim is that low-tech industries may remain important growth drivers in advanced economies. This conclusion is again at variance with recent orthodox industrial policies, which tend to discourage investment in traditional sectors and promote R\&D expenditure in high-tech industries (see, for example, OECD, 2010 and EUROPEAN COMMISSION, 2010a) because of their higher productivity growth rates (LuCAS, 1988, Grossman \& HELPMAN, 1991 and FAGERBERG, 2000).

The rest of the paper proceeds as follows. Section 2 presents the data and the model specification. Section 3 outlines the testing framework which includes unit root tests, cointegration tests and panel Granger causality analysis. Section 4 reports the estimated long-run export price and income elasticities of the leading countries in international

\footnotetext{
${ }^{4}$ In this paper, elasticities are considered in their absolute value. An increase in elasticity, in absolute value, will thus imply a decrease in its algebraic value and vice versa.
} 
food trade. Robustness checks on parameter stability are also performed. Section 5 concludes and hints at the main policy implications of our results.

\section{Model Specification and Data}

We start by selecting the top fifteen food exporters in the world, using as a ranking criterion their export performance in 2011, the last year for which complete data are available. The countries selected are Argentina, Brazil, Belgium, Canada, China, France, Germany, Indonesia, Italy, Malaysia, the Netherlands, Spain, Thailand, the UK and the USA. They constitute a very heterogeneous sample: Argentina, Brazil, China, Malaysia and Thailand are classified by the World Bank as Upper Middle-Income countries; Indonesia is a Lower Middle-Income country; all other countries are High Income OECD members. ${ }^{5}$ Table 2 reports the export values and market shares in 2011 of these fifteen countries, which together account for 62.38 per cent of world food exports. The USA, with an export value of 131,254 million USD and a market share of 9.68 per cent, is the top food exporter, followed by the Netherlands, Germany, Brazil and France (6.42, 5.87 5.71 and 5.61 per cent respectively). The UK is the bottom country in the table, with a share of 2.23 per cent of world food trade.

Table 2 about here

The data used for our estimates, disaggregated at the 3 and 4 digit level according to the Standard International Trade Classification (Rev. 3), are taken from the UN Comtrade database. The analysis considers only processed goods, and the final selection includes 33 goods for each country between 1992 and 2011. ${ }^{6}$ Belgium was excluded from the sample because of incomplete records before 1999. The available data are organized into fourteen distinct panel datasets, one for each of the remaining countries.

\footnotetext{
${ }^{5}$ According to the World Bank classification, based on estimates of gross national income (GNI), Lower Middle-Income countries have a GNI between 1,036 and 4,085 USD, Upper Middle-Income countries have a GNI between 4,086 and 12,615 USD, while High Income countries are characterized by a GNI equal to or greater than 12,616 USD.

${ }^{6}$ We exclude cereals and other raw materials from our analysis. The complete list of goods selected is reported in Table A1 in the Appendix.
} 
Each balanced panel is then characterized by 33 cross-sections (the selected goods) spanning the period 1992-2011, with a total of 660 observations.

Table 3 about here

Descriptive statistics of export volumes, market shares and AUVs are shown in Table 3, which reports the level of these variables at the beginning and the end of the time period, together with the average value for the same time interval. ${ }^{7,8}$ Export volumes increase considerably in most countries. In particular, they more than double in Argentina, Italy, Malaysia, the Netherlands, Spain, the UK and the USA, and rise even more in Brazil, Canada and China. On the other hand, export volumes remain constant in Indonesia and Thailand. Market shares more than double for Argentina, Brazil, Canada, China and the USA, while they decrease in the other developing countries (Indonesia, Malaysia and Thailand) and in all European countries (France, Germany, Italy, Netherlands and the UK), with Spain as the only exception. The highest AUVs are on average recorded by the UK (1.74), the Netherlands (1.50), Germany (1.49) and Italy (1.43), while Thailand and Brazil present the lowest AUVs (0.42 and 0.74 respectively).

Our empirical analysis is based on the following traditional export function:

$$
\ln X_{i t}=\alpha_{i}+\beta_{1 i} \ln R P_{i t}+\gamma_{1 i} \ln G D P W_{t}+\varepsilon_{i t}
$$

where $i$ and $t$ refer to the $i$-th good and the $t$-th year respectively, with $i=1, \ldots, N$ and $t=1, \ldots, T . X_{i t}$ is the yearly export volume for each of the 33 goods; $R P_{i t}$ is the yearly relative export price of each good $;{ }^{9} G D P W_{t}$ is the annual world GDP in constant 2005 USD, which is invariant for each cross-section. All variables are transformed into natural logarithms and labelled $\ln X_{i t}, \ln R P_{i t}$ and $\ln G D P W_{t}$. The coefficients $\beta_{1 i}$ and $\gamma_{1 i}$ are the food export price and income elasticities, respectively. $\beta_{1 i}$ is expected to be

\footnotetext{
${ }^{7}$ Hereafter, export market shares indicate the ratios between the export volume of each country and the total export volume of the 14 countries considered in the analysis.

${ }^{8}$ The export unit values for each good and country are computed by dividing export values by their volumes. Similarly, average export unit values for each good of the whole sample countries are obtained by dividing total export values of each good by their total volumes.

${ }_{9}$ This relative price is obtained as the ratio between the export unit value of each selected country for every good $i$ at time $t$ and the average export unit value of all countries considered for the same good and time.
} 
negative, and $\gamma_{1 i}$ positive. The $\alpha_{i}$ are the intercepts for each good, and the $\varepsilon_{i t}$ the error terms. Equation (1) is estimated for each country in the sample.

\section{A causality analysis between export volumes, relative prices and world income}

\subsection{Panel unit root tests}

Before estimating Equation (1), we perform a panel Granger-type causality test to verify the existence of any causal effect between export volumes, relative prices and world income, an issue somewhat overlooked in the empirical literature on the subject. This econometric procedure requires variables to be stationary and to have the same order of integration. For this reason, following the most recent empirical literature (see Costantini \& Martini, 2010; Bashiri Behmiri \& Pires Manso, 2012 and Jaunky, 2012a, b) and in order to avoid inappropriate conclusions about the order of integration of the variables due to the statistical limitations affecting unit root tests, we apply several panel unit root tests. First-generation panel unit root tests are based on the assumption of cross-sectional independence, while second-generation tests are more powerful because they relax this hypothesis and take into account any possible correlation between cross-sections. In this paper we propose two popular firstgeneration panel unit root tests (BREITUNG 2000 and HADRI 2000 respectively) and a second-generation test (PESARAN, 2007), which is appropriate even in the case of very small sample sizes (i.e., when $N$ and $T$ are equal to 10). The null hypothesis of these tests is that all series contain a unit root, with the exception of the Hadri test, whose null hypothesis is that all panels are stationary. As noted by CAMPELL \& PERRON (1991), the inclusion of many lags in the test equation may affect the power of unit root tests; for this reason, given that in our analysis the time period considered is twenty years $(T=20)$, the maximum selected lag length lies between 2 and $3 .^{10}$ These three panel unit root tests are made in order to verify the order of integration between export volumes and relative prices $\left(\ln X_{i t}\right.$ and $\ln R P_{i t}$ respectively), given that world GDP is a time series

\footnotetext{
${ }^{10}$ A lag length equal to 3 is selected for the PESARAN (2007) unit root test for Brazil and Canada and for Brazil and Indonesia in Tables $3 \mathrm{a}$ and $3 \mathrm{~b}$. A lag length equal to 3 is also selected for Argentina and Indonesia for the BREITUNG (2000) unit root test reported in Table $3 \mathrm{~b}$.
} 
invariant across cross-sections. For this reason, we check for the stationarity of this variable by performing two widely used time series unit root tests: the Augmented Dickey-Fuller (ADF) and the Kwiatkowski-Phillips-Schmidt-Shin (KPSS) tests (SAID AND DICKEY, 1984 and KWIATKOWSKI ET AL., 1992, respectively).

Tables $4 \mathrm{a}, 4 \mathrm{~b}$ and $4 \mathrm{c}$ about here

Tables $4 a, 4 b$ and $4 c$ show the results of these unit root tests. All tests clearly indicate the non-stationarity of the variables of interest. In fact the Breitung and Pesaran tests do not reject the null hypothesis of a unit root in the series. Similarly, the Hadri test rejects the null hypothesis of stationarity. Finally, the ADF and KPSS tests in Table 4c confirm the non-stationarity of world GDP $\left(\ln G D P W_{t}\right)$. For these reasons, $\ln X_{i t}, \ln R P_{i t}$ and $\ln G D P W_{t}$ should be properly considered as I(1).

\subsection{Panel cointegration tests}

Given the non-stationarity of the variables of interest, we proceed with the implementation of different panel cointegration tests to verify the existence of a longrun relationship between them. To this end, we perform the PeDroni $(1999,2004)$ and KAO (1999) panel cointegration tests, which extend to panel data the ENGLE-GRANGER (1987) two-stage framework, developed to test cointegration in the case of time series. The idea is to study the residuals of Equation (1), where all variables $\left(\ln X_{i t}, \ln R P_{i t}\right.$ and $\left.\ln G D P W_{t}\right)$ are $\mathrm{I}(1)$. If these variables are cointegrated, the residuals will be $\mathrm{I}(0)$, but if they are not cointegrated, then the residuals will be I(1). The Pedroni test allows for interdependence across cross-sections together with different individual effects in the intercept and slope of the test equation, in order to define the long-run relationship and to ensure that the cointegrating vectors can vary along the cross-sections in the panel. The Pedroni test consists of two different groups of statistics; the first group is composed of four tests (panel- $v$, panel- $\rho$, panel- $p p$ and panel ADF-statistics), which pool the residuals along the within-dimension of the panel (panel tests). The second group, on the other hand, is composed of three other tests (group- $\rho$, group- $p p$, and group ADF-statistics), which pool the residuals along the between-dimension of the panel 
(group tests). The null hypothesis of no cointegration is rejected if at least four out of seven of these statistics are significant. ${ }^{11}$ The KAO (1999) test follows a similar approach but allows for specific intercepts for each cross-section and homogenous coefficients in the first stage; in Equation (1) this implies heterogeneity in the intercepts $\alpha_{i}$ and homogeneity in $\beta_{1 t}$ and $\gamma_{1 i}$ and all coefficient trends to be zero. As the Pedroni test, the Kao test assumes the null hypothesis of no cointegration. Both these two tests are performed with the inclusion of a time trend in the test equation.

Table 5 about here

The Pedroni and Kao tests are used to check for cointegration between the variables of interest in the fourteen panel datasets collected for each top exporter (Table 5). In the case of the Pedroni test, Panel v-Statistic, Panel $\rho$-Statistic and Group $\rho$-Statistic do not reject the null hypothesis of no cointegration for all countries. Similarly, the Group ADF-Statistic only rejects the null hypothesis for Brazil, Indonesia, Thailand, the UK and the USA. The Pedroni test clearly indicates the presence of cointegration for only these last five countries in our sample. On the other hand, the Kao test rejects the null hypothesis in most cases, with China, Thailand and the USA as the only exceptions. Since at least one test rejects the hypothesis of no cointegration for each country, we can conclude that a long-run relationship exists between the variables of our interest. This conclusion does not hold for China, where both the Pedroni and the Kao tests indicate no cointegration. For this reason, China is henceforth excluded from our analysis.

\subsection{Panel Granger causality test}

Given that our variables are non-stationary and cointegrated, we pass to determine the direction of causality between them by means of the two-step Engle-Granger causality procedure (ENGLE \& GRANGER, 1987). In particular, since the aim of the paper is to study price and income elasticities, we need to find the existence of a long-run causality going from prices and income, respectively, to export volumes. First, long-run

\footnotetext{
${ }^{11}$ For the within-dimension, weighted statistics have been calculated as well. They are not reported in the tables, since they confirm the results of unweighted statistics, but are available on request.
} 
equilibrium coefficients are estimated applying the panel Mean Group (MG) estimator proposed by PESARAN \& SMITH (1995) ${ }^{12}$ to the three following Equations:

$$
\begin{aligned}
& \ln X_{i t}=\alpha_{1 i}+\beta_{1 i} \ln R P_{i t}+\gamma_{1 i} \ln G D P W_{t}+\varepsilon_{i t} \\
& \ln R P_{i t}=\alpha_{2 i}+\beta_{2 i} \ln X_{i t}+\gamma_{2 i} \ln G D P W_{t}+\varphi_{i t} \\
& \ln G D P W_{t}=\alpha_{3 i}+\beta_{3 i} \ln X_{i t}+\gamma_{3 i} \ln R P_{i t}+\lambda_{i t} .
\end{aligned}
$$

The MG estimator is particularly appropriate in the case of non-stationary panels with "moderate-T, moderate-N" dimensions, ${ }^{13}$ where moderate typically means about 15 time series and/or cross-section observations (in our case $T=20$ and $N=33$ ).

Next, we insert the lagged residuals from Equations (2a), (2b) and (2c) in a Granger causality model based on a VECM framework (HOLTS-EAKIN ET AL, 1988), which is specified as follows:

$$
\begin{aligned}
& \Delta \ln X_{i t}=\alpha_{i}^{X}+\sum_{l=1}^{p} \theta_{i l}^{X} \Delta \ln X_{i, t-l}+\sum_{m=1}^{q} \eta_{i m}^{X} \Delta \ln R P_{i, t-m}+\sum_{n=1}^{r} \mu_{i n}^{X} \Delta \ln G D P W_{t-n}+\omega_{i}^{X} E C T_{i, t-1}^{X}+u_{i t} \\
& \Delta \ln R P_{i t}=\alpha_{i}^{R P}+\sum_{l=1}^{p} \theta_{i l}^{R P} \Delta \ln R P_{i, t-l}+\sum_{m=1}^{q} \eta_{i n}^{R P} \Delta \ln X_{i, t-m}+\sum_{n=1}^{r} \mu_{i n}^{R P} \Delta \ln G D P W_{t-n}+\omega_{i}^{R P} E C T_{i, t-1}^{R P}+v_{i t} \\
& \Delta \ln G D P W_{t}=\alpha_{i}^{G D P W}+\sum_{l=1}^{p} \theta_{i l}^{G D P W} \Delta \ln G D P W_{t-l}+\sum_{m=1}^{q} \eta_{i m}^{G D P W} \Delta \ln X_{i, t-m}+\sum_{n=1}^{r} \mu_{i n}^{G D P W} \Delta \ln R P_{i, t-n}+\omega_{i}^{G D P W} E C T_{i, t-1}^{G D P W}+\xi_{i t}
\end{aligned}
$$

where $\Delta$ indicates the first difference of the variables and $u_{i t}, v_{i t}$ and $\xi_{i t}$ are the disturbance terms, which are uncorrelated with zero mean. $E C T_{i, t-1}^{X}, E C T_{i, t-1}^{R P}$ and $E C T_{i, t-1}^{G D P W}$ are the Error Correction Terms (ECTs), i.e. the one-period lagged residuals derived from the long-run relationship defined by Equations (2a), (2b) and (2c)

\footnotetext{
${ }^{12}$ Our estimates are computed using the Stata routine proposed by EBERHARDT (2012).

${ }^{13}$ In this paper the MG estimator proposed by PESARAN \& SMITH (1995) is preferred to the more commonly used dynamic OLS (DOLS) or to the fully modified OLS (FMOLS) procedures developed by SAIKKONEN (1991) and PEDRONI (2000) respectively. The MG estimator is more appropriate to our datasets which are characterized by moderate time length $(\mathrm{T}=20)$.
} 
respectively. The coefficients $\theta, \eta$ and $\mu$ in Equations (3a), (3b) and (3c) indicate the short-run responses of the dependent variables. In order to guarantee convergence toward long-run equilibrium, the parameters $\omega_{i}^{X}, \omega_{i}^{R P}$ and $\omega_{i}^{G D P W}$ need to be negative; they represent the speed of adjustment, i.e. they show how fast deviations from the long-run equilibrium of each variable are eliminated. Consequently, if $\omega_{i}$ is large, there is a strong response by all specific variables to a deviation from long-run equilibrium; on the contrary, if $\omega_{i}$ is low, much more time is required to get back to equilibrium after a shock. It is common practice in the literature to determine the lag lengths $p, q$ and $r$ using the Akaike or the Schwarz Information Criteria. In this paper we use the Schwarz Information Criterion, which indicates that $p, q$ and $r$ are equal to 1 .

Given the possible correlation between the lagged dependent variables and the error terms in Equation (3a), (3b) and (3c), ARELlANO \& BOND (1991), ARELLANO \& Bover (1995) and then BLUNDELL \& BOND (1998) develop a two-step difference GMM estimator in order to obtain an unbiased estimate of the parameters of interest taking into account all kinds of correlation and endogeneity problems. For this reason, and similarly to Costantini \& MARTini (2010), BAshiri BehMiRi \& PiRES MANSo (2012) and JAUNKY (2012a,b), we estimate Equation (3a), (3b) and (3c) by applying the system GMM estimator proposed by BLUNDELL \& BOND (1998). ${ }^{14}$

Finally, it is common practice in the literature to test for the existence of a causal relationship between the variables of interest. Three different types of causality (shortrun, long-run and strong causality) can be analyzed by means of a Wald test. Consider for example Equation (3a): the "short-run Granger causality" holds if the following null hypotheses are rejected: $H_{0}: \eta_{i m}^{X}=0$ and $H_{0}: \mu_{i n}^{X}=0$ for all $i, m$ and $n$. It is important to note that long-run and strong causality are more relevant in our analysis. The "long-run Granger causality" is determined by the ECT coefficient, which indicates how fast deviations from long-run equilibrium are eliminated. In this case, the null hypothesis is $H_{0}: \omega_{i}^{X}=0$ for all $i$. Finally, the "strong Granger causality" is

\footnotetext{
${ }^{14}$ Diagnostic statistics of our estimates are available on request to the authors. In particular, following ROODMAN (2009a), the explanatory variables are treated as endogenous and the selected valid instruments always satisfy the rule of thumb 'maximum number of instruments $=\mathrm{N}$ '. Furthermore, the Hansen $J$ statistic exhibits a $p$-value greater than or at least equal to 0.25 . For the sake of parsimony, instruments are also collapsed (see ROODMAN, 2009b). Finally, to control for cross-sectional dependence, time dummies are included in Equations (3a), (3b) and (3c).
} 
verified if the null hypotheses $H_{0}: \omega_{i}^{X}=\eta_{i m}^{X}=0$ and $H_{0}: \omega_{i}^{X}=\mu_{i n}^{X}=0$, jointly hold for all cross-sections. Similar null hypotheses are then tested for Equations (3b) and $(3 c)$.

Table 6 about here

Table 6 reports the results of the Wald tests on the coefficients for our thirteen countries. ${ }^{15}$ In the short run, there is a unidirectional causality from relative prices to export volumes for Argentina, Canada, Italy, the Netherlands and Thailand, while bidirectional causality is found for the USA. World GDP Granger-causes export volumes only for France and Germany. Bidirectional causality is identified for Brazil. More homogeneous results are found in the case of long-run and strong causality. In fact, in the long-run, all countries exhibit a bidirectional causality between relative prices and export volumes, with the exception of Canada and Italy, which show a unidirectional causality from relative prices to export volumes. Finally, strong causality is again found for all countries with regard to both relative prices and world GDP. Canada and Italy are again the exceptions, but only with reference to Equation (3b).

Given that $\ln R P_{i t}$ and $\ln G D P_{t}$ Granger-cause export volumes $\left(\ln X_{i t}\right)$ in the long-run, which is the time horizon of interest, we can proceed to compare the long-run price and income elasticities of the thirteen countries, using Equation (2a) as outlined at the beginning of this subsection.

\section{Long-run price and income elasticities}

Table 7 reports the previously cited long-run price and income elasticities (parameters $\beta_{1 i}$ and $\gamma_{1 i}$ respectively) for each country in our sample.

Table 7 about here

\footnotetext{
15 Since we are interested in the direction of causality between $\ln X_{i t}$ and $\ln R P_{i t}$ (and $\ln G D P W_{t}$ ) in order to understand if relative prices (and income) determine export volumes or vice versa, we only report the results obtained for Equations (3a) and (3b). Estimates of Equation (3c) are available on request.
} 
Relative prices $\left(\ln R P_{i t}\right)$ exhibit the expected negative sign, and are statistically significant for all countries, with Canada and the USA as the only exceptions. For these two countries, the estimated coefficients are not statistically different from zero, thus implying that they have the most rigid food export demands in our sample. ${ }^{16}$ In general, price elasticities are lower than 1 in all countries. This result is in line with previous findings concerning commodity trade in general. As KRUGMAN (1989) points out, exports of different countries are imperfect substitutes and this implies low price elasticities. This is particularly true in the case of food, where trade involves necessary commodities and is also affected by the fact that many goods are perishable. However, some differences are worth noticing. After Canada and the USA, Italy, Germany, the Netherlands and France show the most rigid export demands, with price elasticities varying from -0.49 to -0.54 . Malaysia has the lowest elasticity among the Upper Medium-Income countries (-0.65). Finally, Spain and Thailand show the highest price elasticities in our sample ( -0.82 and -0.92 respectively).

This evidence can be used to verify whether an inverse relationship between AUVs and price elasticities exists. In particular, given the well-known difficulty of finding a measure of product quality for internationally traded goods, it is common practice in the literature to use AUVs as proxies for quality (AIGINGER, 1997 and SCHOTT, 2004) also in the case of agricultural products (see, among others, GELHAR \& PICK, 2002 and FISHER, 2010). Hence we expect that countries with higher AUVs will generally show more rigid demands and vice versa. Figure 1, which reports the position of each country in terms of its AUV (on the horizontal axis) and price elasticity (on the vertical axis) in the time period 1992-2011, demonstrates the validity of this hypothesis. ${ }^{17}$

Figure 1 about here

The size of the circles in the graph reflects the average market share (in volumes) for each country in the same period (see Table 3). The dotted circles indicate the price elasticity estimates which are not statistically different from zero, i.e. those for Canada and the USA. The graph is divided into four quadrants, where the partition lines are the

\footnotetext{
${ }^{16}$ In confirmation of this, zero is contained in the 95 per cent confidence interval.

${ }^{17}$ A simple OLS regression between AUVs and the absolute values of price elasticities confirms this conclusion. In fact, the estimated coefficient is negative and highly statistically significant.
} 
countries average AUV for the x-axis and the average price elasticity for the y-axis. The negative correlation between AUVs and price elasticities is confirmed and countries are generally positioned either in the upper-left (low AUV and high elasticity) or in the bottom-right (high AUV and low elasticity) quadrant. In particular, we find that Low and Upper Middle-Income countries (Argentina, Brazil, Indonesia, Malaysia and Thailand) lie in the upper-left quadrant, together with Spain, the only High Income country in this quadrant. On the other hand, all other High Income nations (France, Germany, Italy, the Netherlands and the USA) lie in the bottom-right quadrant of the figure, indicating that their food exports are characterized by high AUVs and low price elasticities. The UK lies alone in the upper-right quadrant, showing the highest AUV in the whole sample together with a high price elasticity. Canada on the other hand is the only country lying in the bottom-left quadrant, being characterized by a very rigid demand coupled with lower than average unit values. The most plausible explanation for this evidence is a lack of correspondence between AUVs and quality for these two dissimilar countries. Our analysis ultimately confirms that an inverse relationship between price elasticities and AUVs exists. However, high AUVs can be synonymous of high quality only when a country's food exports are also characterized by a low elasticity of foreign demand.

Regarding our findings on export income elasticity, it is worth recalling at the outset that in the empirical international trade literature, its estimated value in the aggregate export function generally exhibits a level higher than two (see, among others, ARIZE, 2001). This is compatible with the evidence that exports show an average annual growth rate greater than GDP. In the food industry, because of the features of agricultural products previously noted, the export income elasticity is obviously smaller, and typically around one (SERRANO \& PINILLA, 2010). ${ }^{18}$ Our analysis confirms that this is on average true, even though there is a remarkable heterogeneity across countries. Emerging economies show values higher than 2, while advanced economies generally present values slightly above 1, with some countries, like France, the Netherlands and the UK, showing values well below 1 .

Our empirical results suggest the possibility of different competitive strategies in international food trade. Competitiveness is essentially based on price in the emerging

\footnotetext{
${ }^{18}$ As already noticed in footnote 1 , in the time period considered, the historical income elasticity of exports is equal to 1.7 , while that of food is only 1.1 .
} 
countries of our sample (Argentina, Brazil, Indonesia, Malaysia and Thailand) and Spain, while it is driven by quality in all other advanced economies (France, Germany, Italy, the Netherlands and the USA). Furthermore, among these, income elasticities foreshadow different growth scenarios: the low estimated values of this parameter, in fact, suggest poor growth prospects for France and the Netherlands, while the opposite conclusion holds for all other countries. This overall evidence, then, suggests an empirical criterion for assessing the sustainability of a trade specialization model based on low-tech traditional goods. High AUVs, if accompanied by a rigid foreign demand and a satisfactory income elasticity, can in fact guarantee a long-lasting structural competitiveness in low-tech sectors even in advanced countries.

To conclude, as a robustness check of the results shown in Table 7, we test whether the relationship between exports, relative prices and world GDP is stable over time. To this purpose, we perform a recursive estimation of Equation (2a). In particular, 10 sets of regressions are run, by defining an initial window of 10 years (1992-2001) and then re-estimating the basic equation adding a successive terminal year each time. These estimates confirm the robustness of our previous results on both price and income elasticities, as reported in Table $7 .^{19}$

\section{Conclusions and policy implications}

This paper investigates the role of price and income elasticities, AUVs and market shares of the top food exporting countries in determining their export performance in the time period 1992-2011 in order to derive conclusions about their future prospects. First of all, a preliminary analysis of causality is conducted in order to assess the possible presence of unit roots and cointegration between export volumes, relative prices and world income. These variables are found to follow an I(1) process and a long-run relationship between them is established. Next, a panel causality test is performed, showing that in the long-run relative prices and world GDP Granger-cause food exports. Long-run estimates are thus analyzed together with AUVs and market shares. In general, estimated price elasticities are lower than 1, reflecting the fact that food products are necessary goods and imperfect substitutes on international markets.

\footnotetext{
${ }^{19}$ These supplementary estimates are available on request to the authors.
} 
However, some differences emerge in a cross-country comparison of our results: the USA, Canada, Italy, Germany, the Netherlands and France exhibit the most rigid foreign demands, while Spain and Thailand record the highest price elasticities in our sample. Recursive regressions confirm the robustness of our results.

In a quite peculiar way, we also find the existence of an inverse relationship between AUVs and export price elasticities, indicating that countries with higher AUVs generally show more rigid export demands and vice versa. This outcome has important policy implications. In fact, the emerging countries in the sample (Argentina, Brazil, Indonesia, Malaysia and Thailand), together with Spain, base their export performance on price competitiveness, as demonstrated by their high price elasticities. Advanced economies (France, Germany, Italy, the Netherlands and the USA) rely on the other hand on quality competition, as shown by their low price elasticities associated with high AUVs. However, it is worth noting that, among advanced countries, Germany, Italy, Canada and the USA are characterized by an income elasticity higher than one, while in France and the Netherlands the same parameter is strictly lower than one, thus indicating poor growth prospects. This overall evidence suggests an empirical criterion for assessing the sustainability of a trade specialization model based on low-tech traditional goods. High-price high-quality goods, in fact, if accompanied by a rigid foreign demand and a satisfactory income elasticity, can guarantee long-lasting structural competitiveness for low-tech sectors even in advanced countries, where investment should be mainly addressed at promoting quality enhancement. ${ }^{20}$

Finally, our analysis also highlights that AUVs can be considered as proxy for quality only when they are examined together with price, income elasticities and market shares. In particular, this claim is true only when high AUVs go along with a rigid foreign demand and a satisfactory income elasticity of exports.

\section{Acknowledgements}

Financial support from the Grant Industria 2015 for the project @ bilita - Nuove Tecnologie per il Made in Italy is acknowledged. We thank Niaz Bashiri Behmiri and Markus Eberhardt for their useful suggestions. We also acknowledge the helpful

\footnotetext{
${ }^{20}$ These conclusions are also in line with the future CAP (Common Agricultural Policy) reform, which will be more oriented to enhance competitiveness and product quality through technological knowledge and innovation in agriculture (for details, see EUROPEAN COMMISSION, 2010b).
} 
comments of all colleagues on a previous version of the present paper. The usual disclaimers apply.

\section{References}

Aiginger, K. 'The Use of Unit Values to Discriminate between Price and Quality Competition', Cambridge Journal of Economics, Vol. 21, (1997) pp. 571-592.

Arellano, M. and Bond, S. 'Some tests of specification for panel data: Monte Carlo evidence and an application to employment equations', Review of Economic Studies, Vol. 58, (1991) pp. 277-97.

Arellano, M. and Bover, O. 'Another look at the instrumental variables estimation of error components models', Journal of Econometrics, Vol. 68, (1995) pp. 29-51.

Arize, A. C., 'Traditional Export demand relation and parameter instability. An empirical investigation', Journal of Economic Studies, Vol. 28, (2001) pp. 378-396.

Bashiri Behmiri, N. and Pires Manso, J. R., 'Crude oil conservation policy hypothesis in OECD (organisation for economic cooperation and development) countries: A multivariate panel Granger causality test', Energy, Vol. 43, (2012) pp. 253-260.

Blundell, R. and Bond, S., 'Initial conditions and moment restrictions in dynamic panel data models' Journal of Econometrics, Vol. 87, (1998) pp. 11-143.

Breitung, J., 'The local power of some unit root tests for panel data' In: B. Baltagi (Ed.), Nonstationary Panels, Panel Cointegration, and Dynamic Panels, Advances in Econometrics, Vol. 15, (2000) pp. 161-178, JAI, Amsterdam.

Campbell, J. Y. and Perron, P.,'Pitfalls and opportunities: what macroeconomists should know about unit roots', In: Blanchard OJ, Fischer S (Eds). NBER Macroeconomics Annual 1991, Vol. 6, MIT Press (1991).

Caporale, G. M., Chiu, M. K. F., 'Estimating income and price elasticities of trade in a cointegration framework', Review of International Economics, Vol. 7, (1999) pp. 254-264. 
Costantini, V. and Martini, C., 'The causality between energy consumption and economic growth: A multi-sectoral analysis using non-stationary cointegrated panel data', Energy Economics, Vol. 32, (2010) pp. 591-603.

Coyle, W., Gehlhar, M., Hertel, T., Wang, Z., and Yu, W., 'Understanding the determinants of structural change in world food markets', American Journal of Agricultural Economics, Vol. 80, (1998) pp. 1051-1061.

Eberhardt, M., 'Estimating panel time-series models with heterogeneous slopes', The Stata Journal Vol. 12, (2012) pp. 61-71.

Engle R. F. and Granger, C. W. J., 'Co-integration and error correction: representation, estimation, and testing', Econometrica, Vol. 55, (1987) pp. 251-76.

Estevadeordal, A., Frantz, B., Taylor, A. M., 'The rise and fall of world trade, 1870-1939', Quarterly Journal of Economics, Vol. CXVIII, (2003) pp. 359-407.

European Commission, Europe 2020: A strategy for smart, sustainable and inclusive growth. Brussels: European Commission, (2010a).

European Commission, The CAP towards 2020: Meeting the food, natural resources and territorial challenges of the future. Brussels, 18.11.2010, (2010b).

Fagerberg, J., 'Technological progress, structural change and productivity growth: a comparative study', Structural Change and Economic Dynamics, Vol. 11, (2000) pp. 393-411.

Fisher, C., 'Food Quality and Product Export Performance: An Empirical Investigation of the EU Situation', Journal of International Food \& Agribusiness Marketing, Vol. 2, (2010) pp. 210-233.

Gelhar, M. and Pick, D., 'Food Trade balances and unit values: What can they reveal about price competition?', Agribusiness: An International Journal, Vol. 18, (2002) pp. 61-67. 
Goldberg, P. K. and Knetter, M. M., 'Goods prices and exchange rates: what have we learned?', Journal of Economic Literature, Vol. 35, (1997) pp. 1243-72.

Grossman, G. M. and Helpman, E., 'Innovation and Growth in the Global Economy' The MIT Press, Cambridge (USA), (1991).

Hadri, K., Testing for Stationarity in heterogeneous panel data. Econometrics Journal, Vol. 3, (2000) pp. 148-161.

Haq, Z. and Meilke, K., 'The Role of Income in Trading-Differentiated Agri-Food Products: The Case of Canada, the United States, and Selected EU Countries' Canadian Journal of Agricultural Economics, Vol. 57, (2009) pp. 343-363.

Holtz-Eakin, D., Newey, W. and Rosen, H. S., 'Estimating vector autoregressions with panel data', Econometrica, Vol. 56, (1988) pp. 1371-95.

Irwin, D. A., 'Long-run trends in world trade and income', World Trade Review, Vol. 1, (2002) pp. 89-100.

Jaunky, V. C., 'Is there a material Kuznets curve for aluminium? Evidence from rich countries', Resources Policy, Vol. 37, (2012a) pp 296-307.

Jaunky, V. C., 'Democracy and economic growth in Sub-Sahara Africa: a panel data approach',. Empirical Economics, (2012b) DOI 10.1007/s00181-012-0633-x.

Kao, C., 'Spurious regression and residual-based tests for cointegration in panel data' Journal of Econometrics, Vol. 90, (1999) pp. 1-44

Krugman, P. R., 'Pricing to market when the exchange rate changes', In: S. W. Arndt and J. D. Richardson (Eds), Real Financial Linkages Among Open Economies. MIT Press, Cambridge, MA (1987).

Krugman, P. R., 'Differences in Income Elasticities and Trends in Real Exchange Rates' European Economic Review, Vol. 33, (1989)pp. 1031-54. 
Kwiatkowski, D., Phillips, P.C.B., Schmidt, P. and Shin, Y., 'Testing the null hypothesis of stationarity against the alternative of a unit root: how sure are we that economic time series have a unit root?' Journal of Econometrics, Vol. 54, (1992) pp. 159-178.

Lucas, R. E., 'On the mechanisms of economic development' Journal of Monetary Economics, Vol. 22, (1988) pp. 3-42.

OECD Science, Technology and Industry Outlook 2010.

Pedroni, P.,'Critical values for cointegration tests in heterogeneous panels with multiple regressors', Oxford Bulletin of Economics and Statistics, Vol. 61, (1999) pp. 653-670.

Pedroni, P., 'Fully modified OLS for the heterogeneous cointegrated panels', Advances in Econometrics, Vol. 15, (2000) pp. 93-130.

Pedroni, P. 'Panel Cointegration; Asymptotic and Finite Sample Properties of Pooled Time Series Tests with an Application to the PPP Hypothesis', Econometric Theory, Vol. 20, (2004)pp. 597-625.

Pesaran, M. H., 'A simple panel unit root test in the presence of cross section dependence', Journal of Applied Econometrics, Vol. 22, (2007) pp. 265-312.

Pesaran, M. H. and Smith, R. P, 'Estimating long-run relationships from dynamic heterogeneous panels' Journal of Econometrics, Vol. 68, (1995) pp. 79-113.

Roodman, D. M., 'How to Do xtabond2: An Introduction to "Difference" and "System" GMM in Stata', The Stata Journal, Vol. 9, (2009a) pp. 86-136.

Roodman, D. M,. 'A note on the theme of too many instruments', Oxford Bulletin of Economics and Statistics, Vol. 71, (2009b) pp. 135-158.

Said, E. and Dickey, D. A., 'Testing for Unit Roots in Autoregressive Moving Average Models of Unknown Order', Biometrika, Vol. 71, (1984) pp. 599-607. 
Saikkonen, P., 'Asymptotic efficient estimation of cointegration regressions', Econometric Theory, Vol. 7, (1991) pp. 1-21.

Schott, P., 'Across-product versus within-product specialization in international trade', Quarterly Journal of Economics, Vol. 119, (2004) pp. 647-678.

Serrano R. and Pinilla, V., 'Causes of world trade growth in agricultural and food products, 1951-2000: a demand function approach' Applied Economics, Vol. 42, (2010) pp. 3503-3518. 


\section{TABLES}

Tab. 1 - Share of food on total exports of all commodities, World and selected countries, Beginning-of-Period,End-of-period and Average-of-period percentages

\begin{tabular}{cccccccccccccccc}
\hline & World & Argentina & Brazil & Canada & China & France & Germany & Indonesia & Italy & Malaysia & Netherlands & Spain & Thailand & UK & USA \\
\hline 1992 & 9.37 & 61.15 & 25.53 & 9.40 & 11.35 & 15.26 & 5.42 & 10.18 & 7.09 & 10.48 & 21.22 & 15.19 & 26.06 & 8.16 & 10.53 \\
2011 & 7.41 & 52.62 & 30.23 & 9.65 & 2.85 & 12.76 & 5.44 & 16.35 & 7.67 & 13.91 & 12.99 & 14.61 & 14.11 & 5.99 & 8.87 \\
Average & 7.68 & 49.78 & 28.04 & 7.98 & 5.60 & 11.89 & 4.94 & 12.12 & 6.79 & 9.09 & 15.52 & 14.88 & 16.10 & 6.06 & 8.45 \\
\hline
\end{tabular}

Source: our elaboration on WTO data 
Tab. 2 -Top 15 food exporters: Export Values (Million) in USD and Market Shares (percentages of values) in 2011

\begin{tabular}{lcc}
\hline & Export Values & Market Shares \\
\hline United States & 131,254 & 9.68 \\
Netherlands & 87,098 & 6.42 \\
Germany & 79,610 & 5.87 \\
Brazil & 77,389 & 5.71 \\
France & 76,001 & 5.61 \\
China & 54,168 & 4.00 \\
Spain & 44,400 & 3.28 \\
Argentina & 44,225 & 3.26 \\
Canada & 43,631 & 3.22 \\
Belgium & 41,618 & 3.07 \\
Italy & 40,053 & 2.95 \\
Indonesia & 32,865 & 2.42 \\
Malaysia & 31,716 & 2.34 \\
Thailand & 31,465 & 2.32 \\
United Kingdom & 30,208 & 2.23 \\
World & $1,360,000$ & 62.38 \\
\hline
\end{tabular}

Tab. 3 - Export volumes (in tons), average unit values and market shares (percentages of volumes), Beginningof-Period, End-of-period and Average-of-period values

\begin{tabular}{l|ccc|ccc|ccc}
\hline & \multicolumn{3}{|c|}{ Export volumes } & \multicolumn{3}{c|}{ Market shares } & \multicolumn{3}{c}{ Average unit values } \\
& 1992 & 2011 & Average & 1992 & 2011 & Average & 1992 & 2011 & Average \\
\hline Argentina & 1,788 & 4,838 & 3,487 & 1.82 & 2.28 & 2.34 & 0.97 & 1.71 & 1.07 \\
Brazil & 6,032 & 36,473 & 20,137 & 6.14 & 17.15 & 12.82 & 0.81 & 1.20 & 0.74 \\
Canada & 2,624 & 10,526 & 6,900 & 2.67 & 4.95 & 4.58 & 0.91 & 1.43 & 1.06 \\
China & 6,486 & 20,417 & 11,405 & 6.61 & 9.60 & 7.45 & 0.64 & 1.43 & 0.89 \\
France & 11,834 & 15,517 & 13,898 & 12.05 & 7.30 & 9.98 & 1.28 & 1.93 & 1.39 \\
Germany & 10,527 & 19,595 & 14,268 & 10.72 & 9.21 & 9.83 & 1.25 & 2.36 & 1.49 \\
Indonesia & 2,561 & 2,978 & 2,461 & 2.61 & 1.40 & 1.75 & 0.44 & 1.64 & 0.93 \\
Italy & 5,718 & 10,254 & 8,006 & 5.82 & 4.82 & 5.61 & 1.23 & 2.12 & 1.41 \\
Malaysia & 1,089 & 2,151 & 1,737 & 1.11 & 1.01 & 1.25 & 0.69 & 1.95 & 0.93 \\
Netherlands & 13,292 & 25,055 & 16,894 & 13.54 & 11.78 & 11.79 & 1.48 & 2.02 & 1.50 \\
Spain & 6,536 & 16,533 & 12,359 & 6.66 & 7.77 & 8.51 & 1.02 & 1.60 & 1.14 \\
Thailand & 15,075 & 15,545 & 12,084 & 15.35 & 7.31 & 8.62 & 0.23 & 0.84 & 0.42 \\
UK & 2,598 & 4,216 & 3,648 & 2.65 & 1.98 & 2.57 & 1.90 & 2.41 & 1.74 \\
USA & 12,027 & 28,551 & 18,689 & 12.25 & 13.43 & 12.88 & 1.15 & 1.86 & 1.33 \\
\hline \multicolumn{8}{c}{ Source: our elaboration on WTO data } & &
\end{tabular}


Tab. 4a - Panel Unit Root Test Statistics for the variable $\ln X_{i t}$

\begin{tabular}{lccc}
\hline & Breitung & Hadri & Pesaran \\
\hline Argentina & $0.12(0.56)$ & $11.23(0.00)$ & $-0.38(0.35)$ \\
Brazil & $1.08(0.86)$ & $12.04(0.00)$ & $2.48(0.99)^{\star}$ \\
Canada & $0.87(0.81)$ & $27.73(0.00)$ & $-0.09(0.47)^{\star}$ \\
China & $-0.46(0.32)$ & $13.23(0.00)$ & $2.09(0.98)$ \\
France & $-0.95(0.17)$ & $17.55(0.00)$ & $-0.52(0.30)$ \\
Germany & $-1.16(0.12)$ & $22.64(0.00)$ & $-0.05(0.48)$ \\
Indonesia & $-1.13(0.13)$ & $18.79(0.00)$ & $-0.17(0.43)$ \\
Italy & $-0.68(0.25)$ & $9.12(0.00)$ & $1.13(0.87)$ \\
Malaysia & $-0.26(0.40)$ & $17.79(0.00)$ & $0.93(0.82)$ \\
Netherlands & $1.96(0.97)$ & $18.28(0.00)$ & $-0.42(0.33)$ \\
Spain & $0.21(0.58)$ & $22.37(0.00)$ & $0.86(0.80)$ \\
Thailand & $-0.27(0.39)$ & $14.74(0.00)$ & $4.00(1.00)$ \\
UK & $0.05(0.52)$ & $31.09(0.00)$ & $-0.56(0.28)$ \\
USA & $-0.14(0.44)$ & $24.03(0.00)$ & $-0.38(0.35)$ \\
\hline
\end{tabular}

Notes: Lambda statistic, z statistic and the standardised Z-tbar are reported for the Breitung (2000), Hadri (2000) and Pesaran (2007) unit roots test respectively; p-values in parenthesis; Breitung (2000), Hadri (2000) and Pesaran (2007) tests are calculated by including intercept and time trend in the test equation; Maximum selected lag length is 2 ; A indicates lag length equal to 3; The null hypothesis for all tests is "Panels contain unit roots" with the exception of the Hadri test, whose null hypotesis is "All panels are stationary".

Tab. $4 \mathrm{~b}$ - Panel Unit Root Test Statistic for the variable $\ln R P_{i t}$

\begin{tabular}{lccc}
\hline & Breitung & Hadri & Pesaran \\
\hline Argentina & $0.53(0.71)^{\star}$ & $13.84(0.00)$ & $-0.65(0.26)$ \\
Brazil & $0.97(0.83)$ & $24.16(0.00)$ & $0.35(0.64)^{\star}$ \\
Canada & $1.00(0.84)$ & $11.56(0.00)$ & $1.42(0.92)$ \\
China & $-0.07(0.47)$ & $7.94(0.00)$ & $0.74(0.77)$ \\
France & $0.37(0.64)$ & $10.58(0.00)$ & $0.06(0.52)$ \\
Germany & $0.12(0.55)$ & $11.95(0.00)$ & $-0.34(0.37)$ \\
Indonesia & $-0.09(0.46)^{\star}$ & $6.80(0.00)$ & $2.87(0.61)^{\star}$ \\
Italy & $-0.06(0.52)$ & $9.13(0.00)$ & $2.16(0.98)$ \\
Malaysia & $-0.74(0.23)$ & $8.37(0.00)$ & $-1.15(0.12)$ \\
Netherlands & $-0.36(0.36)$ & $14.20(0.00)$ & $2.45(0.99)$ \\
Spain & $-0.55(0.29)$ & $12.20(0.00)$ & $-0.97(0.83)$ \\
Thailand & $0.47(0.68)$ & $18.34(0.00)$ & $0.58(0.72)$ \\
UK & $-0.80(0.21)$ & $16.70(0.00)$ & $-0.10(0.46)$ \\
USA & $-0.44(0.33)$ & $11.01(0.00)$ & $0.84(0.80)$ \\
\hline
\end{tabular}

Notes: See Table 4a.

Tab. $4 \mathrm{c}$ - Unit Root Tests for the variable $\ln G D P W_{t}$

\begin{tabular}{cc}
\hline ADF & KPSS \\
\hline 0.34 & 0.61 \\
$(0.97)$ & {$[0.46]$}
\end{tabular}

Notes: $T$-statistic and $L M$-statistic are reported for Augmented Dickey-Fuller test (ADF) and Kwiatkowski-PhillipsSchmidt-Shin (KPSS) unit roots tests; p-values and asymptotic critical values in parentheses and brackets; asymptotic critical value of 0.46 corresponds to 5 per cent significance level; ADF and KPSS unit root tests are calculated including the intercept in the test equation; The null hypothesis is "lnGDPW $W_{t}$ has a unit root" for ADF test and "ln $G D P W_{t}$ is stationary" for KPSS test. 
Tab. 5 - Pedroni and Kao Panel Cointegration Tests

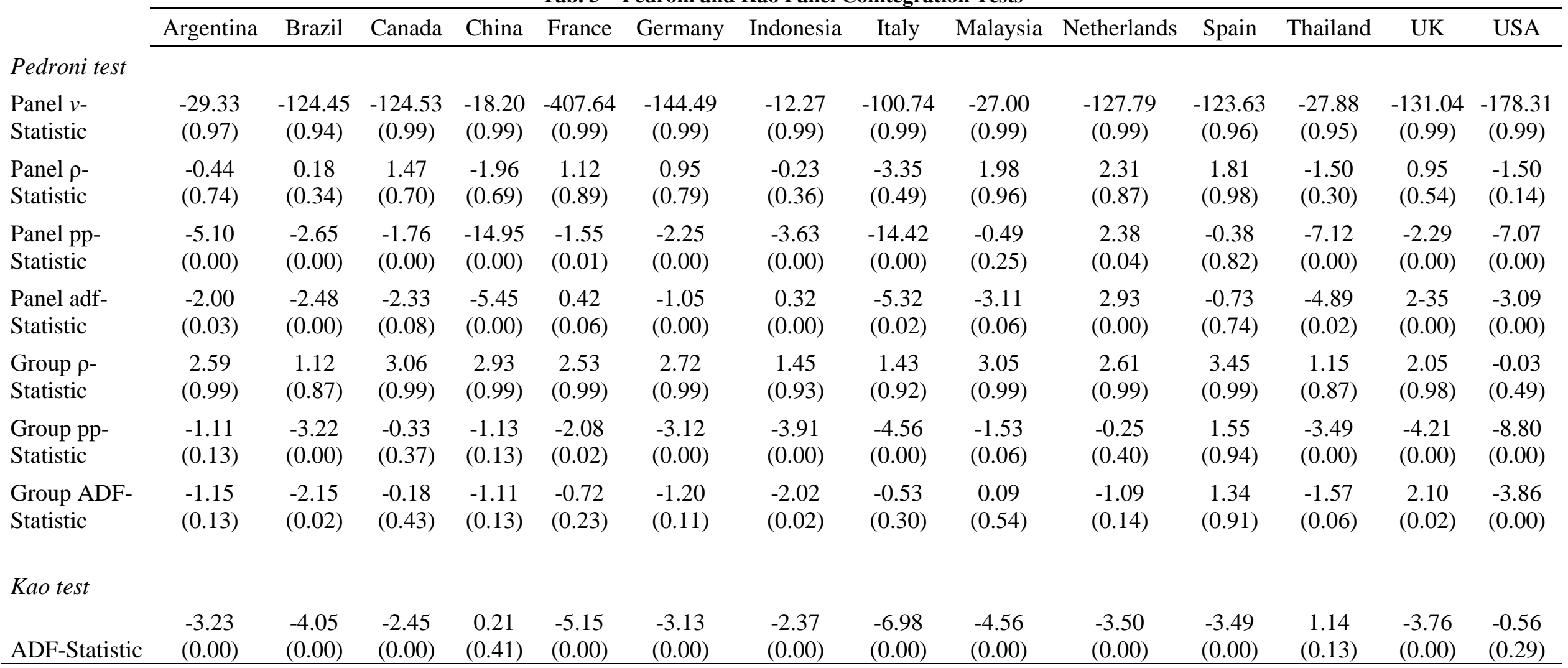

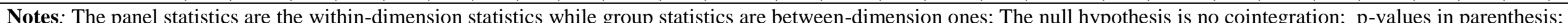

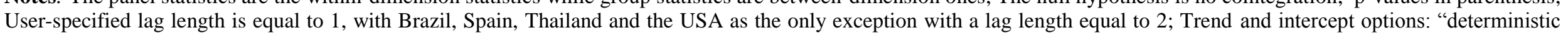
trend and intercept" for all countries. 
Tab. 6 - Panel Granger causality test

\begin{tabular}{|c|c|c|c|c|c|c|c|c|}
\hline & \multicolumn{3}{|c|}{ Short-run } & \multirow{2}{*}{$\begin{array}{c}\text { Long-run } \\
\text { ECT }\end{array}$} & \multicolumn{3}{|c|}{ Strong causality } \\
\hline & & $\Delta \ln X_{i t}$ & $\Delta \ln R P_{i t}$ & $\triangle \ln G D P W_{t}$ & & $\mathrm{ECT} / \Delta \ln X_{i t}$ & $\mathrm{ECT} / \Delta \ln R P_{i \mathrm{t}}$ & $\mathrm{ECT} / \Delta \ln G D P W_{t}$ \\
\hline \multirow{2}{*}{ Argentina } & $\Delta \ln X_{i t}$ & - & $10.33 * * *$ & 0.06 & $2.93 *$ & - & $6.14 * * *$ & 6.14 \\
\hline & $\Delta \ln R P_{i t}$ & 1.19 & - & $12.26 * * *$ & $11.11 * * *$ & $5.70 * * *$ & - & $6.72 * * *$ \\
\hline \multirow{2}{*}{ Brazil } & $\Delta \ln X_{i t}$ & - & 0.29 & $5.08 * *$ & $51.57 * * *$ & - & $43.80 * * *$ & $31.08 * * *$ \\
\hline & $\Delta \ln R P_{i t}$ & 0.49 & - & $11.86 * * *$ & $10.34 * * *$ & $5.20 * *$ & - & $25.50 * * *$ \\
\hline \multirow{2}{*}{ Canada } & $\Delta \ln X_{i t}$ & - & $5.36 * *$ & 2.61 & $18.77 * * *$ & - & $24.78 * *$ & $14.42 * * *$ \\
\hline & $\Delta \ln R P_{i t}$ & 0.20 & - & 0.03 & 0.68 & 0.46 & - & $1.06 * * *$ \\
\hline \multirow{2}{*}{ France } & $\Delta \ln X_{i t}$ & - & 1.18 & $5.33 * *$ & $9.13 * * *$ & - & $4.63 * *$ & $12.78 * * *$ \\
\hline & $\Delta \ln R P_{i t}$ & $4.88 * *$ & - & 2.48 & $4.69 * *$ & $3.27 *$ & - & $2.83 *$ \\
\hline \multirow{2}{*}{ Germany } & $\Delta \ln X_{i t}$ & - & 2.08 & $3.11^{*}$ & $25.79 * * *$ & - & $13.04 * * *$ & $12.97 * * *$ \\
\hline & $\Delta \ln R P_{i t}$ & 0.14 & - & 0.87 & $29.94 * * *$ & $16.19 * * *$ & - & $15.11 * * *$ \\
\hline \multirow{2}{*}{ Indonesia } & $\Delta \ln X_{i t}$ & - & 0.28 & 0.07 & $4.49 * *$ & - & $8.55 * * *$ & $4.04 * *$ \\
\hline & $\Delta \ln R P_{i t}$ & 0.24 & - & 0.48 & $27.19 * * *$ & $37.01 * * *$ & - & $16.17 * * *$ \\
\hline \multirow{2}{*}{ Italy } & $\Delta \ln X_{i t}$ & - & $15.04 * * *$ & 1.87 & $7.76 * * *$ & - & $8.21 * * *$ & $5.99 * * *$ \\
\hline & $\Delta \ln R P_{i t}$ & 1.43 & - & 0.24 & 1.67 & $10.63 * * *$ & - & 0.85 \\
\hline \multirow{2}{*}{ Malaysia } & $\Delta \ln X_{i t}$ & - & 0.80 & 2.79 & $10.11 * * *$ & - & $7.01 * * *$ & $6.23 * * *$ \\
\hline & $\Delta \ln R P_{i t}$ & 0.06 & - & $6.89 * *$ & $11.30 * * *$ & $7.55 * * *$ & - & $8.92 * * *$ \\
\hline \multirow{2}{*}{ Netherlands } & $\Delta \ln X_{i t}$ & - & $4.64 * * *$ & 0.63 & $13.94 * * *$ & - & $9.71 * * *$ & $7.12 * * *$ \\
\hline & $\Delta \ln R P_{i t}$ & 0.29 & - & 2.58 & $26.58 * * *$ & $33.08 * * *$ & - & $14.33 * * *$ \\
\hline \multirow{2}{*}{ Spain } & $\Delta \ln X_{i t}$ & - & 1.81 & 1.76 & $20.68 * * *$ & - & $11.34 * * *$ & $10.36^{* * *}$ \\
\hline & $\Delta \ln R P_{i t}$ & 0.00 & - & 1.33 & $24.92 * *$ & $108.28 * * *$ & - & $13.20 * * *$ \\
\hline \multirow{2}{*}{ Thailand } & $\Delta \ln X_{i t}$ & - & $3.24 *$ & 0.06 & $13.75 * * *$ & - & $9.43 * * *$ & $7.52 * * *$ \\
\hline & $\Delta \ln R P_{i t}$ & 0.07 & - & $8.74 * * *$ & $12.24 * * *$ & $8.72 * * *$ & - & $9.03 * * *$ \\
\hline \multirow{2}{*}{ UK } & $\Delta \ln X_{i t}$ & - & 0.11 & 0.00 & $14.56^{* * * *}$ & - & $13.18 * * *$ & $7.71 * * *$ \\
\hline & $\Delta \ln R P_{i t}$ & 1.55 & - & $5.30 * *$ & $23.71 * * *$ & $20.49 * * *$ & - & $12.09 * * *$ \\
\hline \multirow{2}{*}{ USA } & $\Delta \ln X_{i t}$ & - & $10.65 * * *$ & 1.25 & $33.29 * * *$ & - & $17.89 * * *$ & $32.01 * * *$ \\
\hline & $\Delta \ln R P_{i t}$ & $31.74 * * *$ & - & 2.29 & $38.28 * * *$ & $50.83 * * *$ & - & $28.84 * * *$ \\
\hline
\end{tabular}

Notes: $*(* *)[* * *]$ indicates significance at $10(5)[1]$ per cent level. 
Tab. 7 - Long-run estimates of Equation (2a)

\begin{tabular}{|c|c|c|c|c|c|c|c|c|c|c|c|c|c|}
\hline & Argentina & Brazil & Canada & France & Germany & Indonesia & Italy & Malaysia & Netherlands & Spain & Thailand & $\mathbf{U K}$ & USA \\
\hline $\ln R P_{i t}$ & $\begin{array}{c}-0.72 * * * \\
(0.18)\end{array}$ & $\begin{array}{c}-0.75 * * * \\
(0.17)\end{array}$ & $\begin{array}{l}-0.27 \\
(0.19)\end{array}$ & $\begin{array}{c}-0.54 * * * \\
(0.12)\end{array}$ & $\begin{array}{c}-0.50 * * * \\
(0.14)\end{array}$ & $\begin{array}{c}-0.81 * * * \\
(0.16)\end{array}$ & $\begin{array}{c}-0.49 * * * \\
(0.17)\end{array}$ & $\begin{array}{c}-0.69 * * * \\
(0.18)\end{array}$ & $\begin{array}{c}-0.52 * * * \\
(0.10)\end{array}$ & $\begin{array}{c}-0.82 * * * \\
(0.15)\end{array}$ & $\begin{array}{c}-0.92 * * * \\
(0.18)\end{array}$ & $\begin{array}{c}-0.75 * * * \\
(0.15)\end{array}$ & $\begin{array}{l}-0.12 \\
(0.17)\end{array}$ \\
\hline $\ln G D P W_{t}$ & $\begin{array}{c}2.00 * * * \\
(0.52)\end{array}$ & $\begin{array}{c}2.89 * * * \\
(0.43)\end{array}$ & $\begin{array}{c}1.45^{* * * *} \\
(0.23)\end{array}$ & $\begin{array}{c}0.69 * * * \\
(0.16)\end{array}$ & $\begin{array}{c}1.84 * * * \\
(0.21)\end{array}$ & $\begin{array}{c}2.06^{* * * *} \\
(0.58)\end{array}$ & $\begin{array}{c}1.63 * * * \\
(0.25)\end{array}$ & $\begin{array}{c}1.71 * * * \\
(0.35)\end{array}$ & $\begin{array}{c}0.83 * * * \\
(0.22)\end{array}$ & $\begin{array}{c}2.23 * * * \\
(0.29)\end{array}$ & $\begin{array}{c}2.76^{* * * *} \\
(0.55)\end{array}$ & $\begin{array}{c}0.61 * * * \\
(0.16)\end{array}$ & $\begin{array}{c}1.15 * * * \\
(0.19)\end{array}$ \\
\hline Constant & $\begin{array}{l}-5.58 \\
(5.44) \\
\end{array}$ & $\begin{array}{c}-13.91 * * * \\
(4.76)\end{array}$ & $\begin{array}{c}1.83 \\
(2.37) \\
\end{array}$ & $\begin{array}{c}11.03 * * * \\
(1.75)\end{array}$ & $\begin{array}{l}-1.08 \\
(2.34) \\
\end{array}$ & $\begin{array}{l}-7.66 \\
(6.26) \\
\end{array}$ & $\begin{array}{c}0.19 \\
(2.80)\end{array}$ & $\begin{array}{l}-2.72 \\
(3.67) \\
\end{array}$ & $\begin{array}{c}9.80 * * * \\
(2.42)\end{array}$ & $\begin{array}{l}-6.21 * \\
(3.27)\end{array}$ & $\begin{array}{c}-13.36^{* * *} \\
(6.12)\end{array}$ & $\begin{array}{c}10.89 * * * \\
(1.86)\end{array}$ & $\begin{array}{c}6.35 * * * \\
(1.99)\end{array}$ \\
\hline
\end{tabular}




\section{FIGURE}

Figure 1 - Positioning of the sample countries in terms of AUV and price elasticity, years 1992- 2011

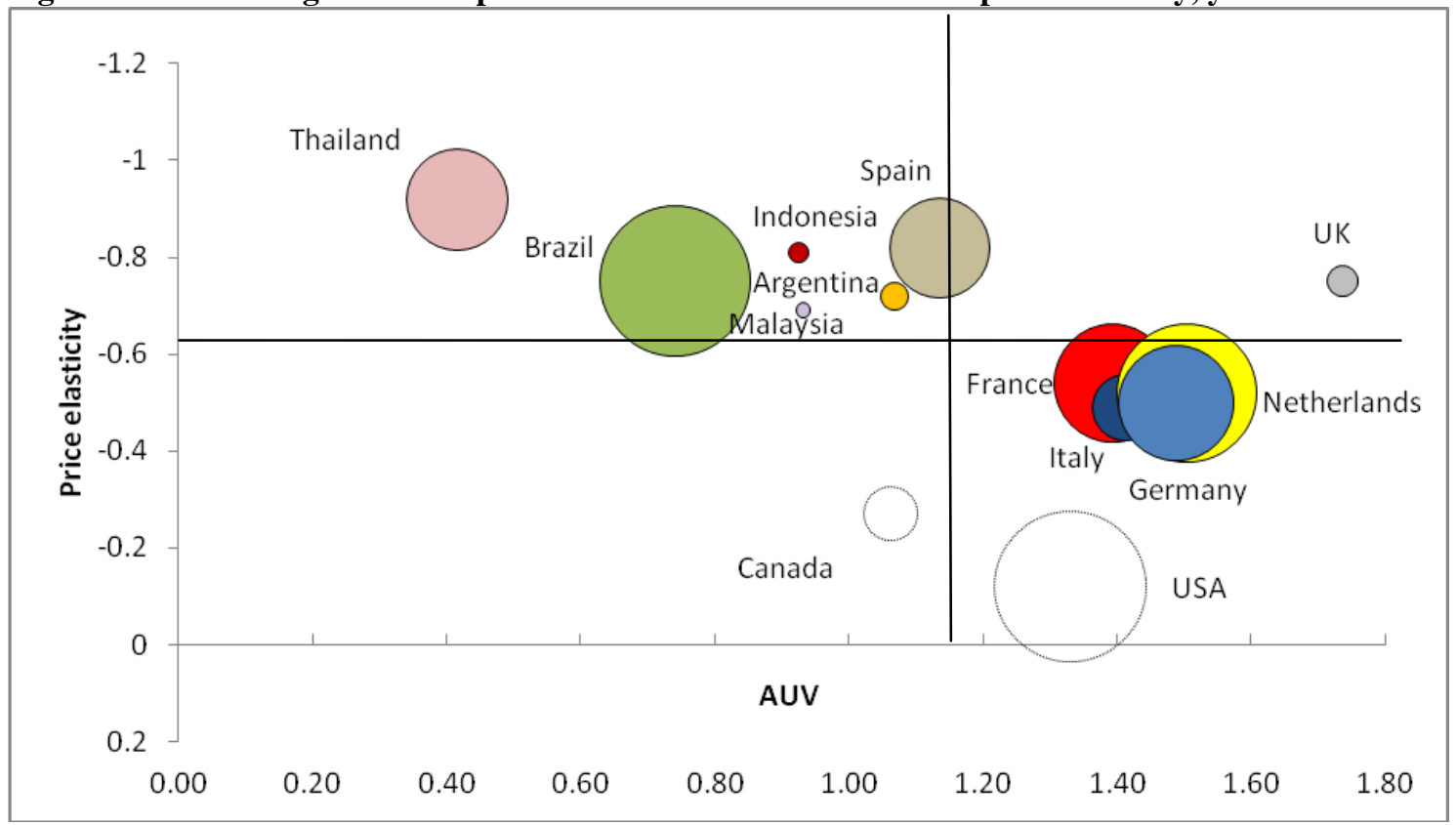

Notes: Estimated values of price elasticities are provided in Table 7; the size of the circles is given by the average market share in volumes in the period 1992-2011; dotted circles indicate not statistically significant estimates. 


\section{APPENDIX}

Tab. A1 - Detail of the Food products according to the SITC Classification Rev. 3

Commodity Code and Description

01 MEAT, MEAT PREPARATIONS

011 Bovine meat

012 Other meat, meat offal

016 Meat, Offal, Dry, Salted, Smoked

0171 Extracts and juices of meat, fish, crustaceans or mollusks

0172 Sausages and similar products, of meat, meat offal or blood

0173 Liver of any animal, prepared or preserved

0174 Meat and offal (other than liver) of poultry

0175 Meat and offal (other than liver) of swine

0176 Meat and offal (other than liver) of bovine animals

02 DAIRY PRODUCTS, BIRD EGGS

022 Milk and cream

023 Butter, other fat of milk

024 Cheese and curd

025 Eggs, birds, yolks, albumin

05 VEGETABLES AND FRUITS

054 Vegetables

056 Vegetables, prepared, preserved

057 Fruits, nuts with the exclusion of oil nuts

058 Fruits, prepared, preserved

059 Fruits, vegetables juices

06 SUGAR, HONEY

061 Sugars, molasses, honey

062 Sugar confectionery

07 COFFEE, TEA, COCOA, SPICES

071 Coffee, coffee substitute

072 Cocoa

073 Chocolate and other cocoa preparation

074 Tea and mate

075 Spice

09 EDITABLE PRODUCTS PREPARATIONS

0981 Homogenized food preparation

0984 Sauce, seasoning, condiment

0985 Soups and broths and preparations

0986 Yeasts (active or inactive)

09891 Pasta, cooked or stuffed; couscous

09893 Food preparations for infant use, put up for retail

09894 Malt extract

09899 Other food preparations

Notes: Only 3 and 4 digit level goods are used in the empirical analysis; commodity code is in bold. 